\title{
PENINGKATAN KEMAMPUAN PENGGUNAAN MICROSOFT OFFICE 365 MELALUI PELATIHAN DAN SIMULASI PADA GURU SEKOLAH DASAR
}

\author{
Binti Ngatmiyatun \\ SD Negeri 3 Belikurip \\ bunda.binti@gmail.com
}

\begin{abstract}
Abstrak
Tujuan penelitian ini adalah untuk meningkatkan kemampuan guru SD Negeri 3 Belikurip dalam menggunakan program Microsoft Office 365 sebagai media pembelajaran melalui pelatihan dan simulasi. Penelitian ini merupakan Penelitian Tindakan Sekolah (PTS) yang dilaksanakan dalam 2 (dua) siklus. Subjek penelitian adalah 8 orang guru SD Negeri 3 Belikurip. Penilaian kemampuan guru dilakukan dengan observasi menggunakan pedoman observasi. Validasi data dilakukan dengan teknik triangulasi. Analisis data dilakukan dengan teknik analisis deskriptif komparatif. Pada kondisi awal hanya 2 orang guru $(25,0 \%)$ yang kualifikasinya Baik dengan nilai rata-rata kompetensi guru hanya 59,5 (Cukup). Meningkat pada siklus I menjadi ada 1 orang (12,5\%) yang kemampuannya Amat Baik dan 3 orang guru $(37,5 \%)$ yang kemampuannya Baik dengan nilai rata-rata kompetensi guru adalah 70,3 (Cukup). Meningkat lagi pada siklus II menjadi 2 orang guru $(25,0 \%)$ yang kemampuannya Amat Baik dan sebanyak 6 orang guru $(75,0 \%)$ yang kemampuannya Baik dengan nilai rata-rata kompetensi guru 81,1 (Baik). Sehingga disimpulkan bahwa pelatihan dan simulasi dapat meningkatkan kemampuan menggunakan program Microsoft Microsoft Office 365 sebagai media pembelajaran pada guru SD Negeri 3 Belikurip Tahun Pelajaran 2019/2020.
\end{abstract}

Kata kunci: kemampuan guru, Microsoft Office 365 , pelatihan dan simulasi

\begin{abstract}
The purpose of this study is to improve the ability of SD Negeri 3 Belikurip teachers to use the Microsoft Office 365 program as a learning medium through training and simulation. This research is a School Action Research (PTS) which was carried out in 2 (two) cycles. The research subjects were 8 teachers of SD Negeri 3 Belikurip. Assessment of teacher abilities is carried out by observation using observation guidelines. The data validation was done by using triangulation technique. Data analysis was performed using comparative descriptive analysis techniques. In the initial condition, only 2 teachers (25.0\%) had good qualifications with an average teacher competency score of only 59.5 (Enough). Increased in the first cycle to be 1 person (12.5\%) whose ability is Very Good and 3 teachers (37.5\%) whose ability is Good with an average score of teacher competence is 70.3 (Enough). Increased again in the second cycle to 2 teachers (25.0\%) whose abilities were Very Good and as many as 6 teachers (75.0\%) whose abilities were Good with an average score of teacher competence of 81.1 (Good). So it is concluded that training and simulation can improve the ability to use the Microsoft Microsoft Office 365 program as a learning medium for teachers of SD Negeri 3 Belikurip for the 2019/2020 academic year.
\end{abstract}

Keywords: teacher ability, Microsoft Office 365, training and simulation

\section{PENDAHULUAN}

Kegiatan proses belajar mengajar
sering ditemukan adanya kesulitan
kesulitan dari segi interaksi dalam
menyampaikan bahan kepada siswa.
Pembelajaran adalah proses interaksi antara peserta didik, guru dan lingkungan belajar (Nurgiansah, Hendri, et al., 2021). Hal ini bisa terjadi karena intelegensi dan daya tangkap siswa yang berbeda-beda atau kurang jelasnya keterangan dari guru, baikdari segi suara, tulisan maupun juga dikarenakan guru kurang profesional dalam menggunakan metode mengajar dan media pembelajaran (Khoirudin, 2019).

Penggunaan media pembelajaran yang tepat mempunyai manfaat yang besar sesuai dengan kegiatan pembelajaran (Miftah, 2014). Media pembelajaran penting dalam proses pembelajaran, 
adanya media mendukung proses komunikasi yang dilakukan oleh guru sehingga dapat optimal (Falahudin, 2014). Media pembelajaran yang dimaksud adalah alat bantu dalam mengajar untuk menyalurkan informasi dari guru kepada peserta didik sehingga dapat merangsang pikiran, perasaan, perhatian dan semangat peserta didik untuk belajar. Penggunaan media merupakan bagian yang perlu diperhatikan guru dalam kegiatan pembelajaran. Namun pada kenyataannya media pembelajaran masih kurang diperhatikan.

Hal yang terlihat sekarang, masih banyak guru kurang mampu menggunakan media pengajaran yang tersedia di sekolah, misalnya pembelajaran hanya dititikberatkan pada penguasaan bidang materi saja sedangkan di bidang pengalaman kurang terpenuhi. Guru merupakan salah satu faktor utama yang menentukan mutu pendidikan (Nurgiansah, 2021). Dalam pengajaran di sekolah dasar dengan konsep tematik pun media sangat diperlukan sebagai alas untuk membantu seorang guru dalam memberikan suatu penjelasan, baik itu bersifat kongkrit, maupun abstrak. Akan tetapi dalam penggunaan media ini diperlukan suatu keterampilan dan kekreatifan yang dituntut pada seorang guru untuk menggunakan berbagai media, terutama sarana dan prasarana, yang dimiliki oleh sekolah serta pemanfaatan lingkungan sebagai media dalam proses belajar mengajar.

Sebagaimana yang dijelaskan oleh Usman dan Lilis (2001: 4) bahwa penggunaan media di suatu pendidikan merupakan dasar yang sangat penting dan diperlukan yang bersifat melengkapi dan merupakan bagian integral demi berhasilnya proses pendidikan dan pengajaran di sekolah. Untuk mencapai tujuan pendidikan tersebut diperlukan peningkatan kualitas sumber daya manusia
(SDM) dan kualitas proses pembelajaran. Salah satu faktor yang mempengaruhi keberhasilan dalam proses pembelajaran adalah penggunaan media pembelajaran, baik benda-benda asli maupun tiruan yang relevan dengan konsep (Muhson, 2010). Disamping media pembelajaran yang merupakan salah satu sumber belajar yang penting, media pembelajaran juga dapat membantu para guru untuk memperjelas dan memvisualisasikan konsep kepada para peserta didik dalam mencapai ketrampilan tertentu. Sejalan dengan perkembangan zaman dapat ditandai dengan kemajuan ilmu pengetahuan dan tehnologi canggih. Karena itu dalam proses belajar mengajar perlu juga dikembangkan cara cara mengajar yang baru. Diantaranya yaitu cara mengajar dengan menggunakan media komputer dan salah satunya pengoperasian Microsoft Office 365 (Suprianto, 2018).

Pendemi Covid 19 memberikan perubahan yang mendasar terhadap pola pembelajaran saat ini terlihat masif dilakukan di semua jenjang pendidikan (Siahaan, 2020). Penelitian ini bertujauan untuk mengupas secara teoritis berdasarkan studi pustaka pembelajaran online berbasis problem based learning di tengah pandemi Covid-19 yang berefek pada kebijakan belajar di rumah. Sistem pembelajaran online berbasis problem based learning memberikan banyak peluang untuk mengakses bahan ajar oleh warga pembelajar(Handayani \& Hadi, 2020). Banyak media online yang bisa diakses melalui jaringan internet oleh pengajar maupun peserta didik. Beberapa media online gratis yang sudah terbukti efektif dalam pengelolaan pembelajaran online secara klasikal diantaranya adalah Microsoft Office 365. Beberapa hal yang menjadi kendala dalam penerapan pembelajaran online diantaranya kuota internet yang terbatas dan masih belum familiarnya tenaga pendidik beserta 
peserta didik dalam mengaplikasikannya. Oleh karena itu perlu adanya upaya khusus yang lebih masif untuk mengatasi problematika ini mulai dari individu masing-masing, dukungan keluarga, lembaga/institusi pendidikan, jasa provider dan pemerintah. Salah satu pendekatan pembelajaran yang dapat memaksimalkan pembelajaran online adalah pembelajaran berbasis proyek. Pembelajaran ini memberikan peluang kepada peserta didik untuk mempelajari konsep secara mendalam sekaligus juga dapat meningkatkan hasil belajar mereka.

Berdasarkan pengamatan awal yang penulis lakukan di SD Negeri 3 Belikurip Tahun Pelajaran 2019/2020 peneliti menemukan masalah-masalah para guru SD Negeri 3 Belikurip sebagai berikut: 1) Kemampuan para guru dalam menggunakan Microsoft Office 365 sebagai media pembelajaran masih rendah; 2) Kualitas proses pembelajaran dengan menggunakan media Microsoft Office 365 pembelajaran yang sudah dibuat oleh guru masih belum optimal; dan 3) Para guru kurang termotivasi dan belum percaya diri dalam menggunakan Microsoft Office 365 sebagai media pembelajaran. Sedangkan secara empiris diperoleh fakta bahwa tidak ada guru yang kemampuanya masuk kualifikasi Amat Baik, hanya 2 orang guru $(25,0 \%)$ yang kualifikasinya Baik, ada 4 orang guru $(50,0 \%)$ yang kualifikasinya Cukup dan masih ada 2 orang guru $(25,0 \%)$ yang kualifikasinya Kurang. Perkembangan zaman mengharuskan guru untuk terus berkembang dan meningkatkan kompetensinya (Nurgiansah \& Pringgowijoyo, 2020).

Permasalahan rendahnya

kemampuan guru SD Negeri 3 Belikurip Tahun Pelajaran 2019/2020 dalam menggunakan Microsoft Office 365 sebagai media pembelajaran akan berpengaruh terhadap perbaikan kualitas proses pembelajaran. Karena dalam beberapa mata pembelajaran, banyak menggunakan ilustrasi gambar, grafik, konsep yang harus ditampilkan secara visual dalam proses pembelajarannya. Sehingga sangat sulit jika hanya dijelaskan dengan metode ceramah. Berdasarkan fakta tersebut, maka penulis berencana untuk melaksanakan suatu Penelitian Tindkdan Sekolah (PTS) melalui pelaksanaan pelatihan dan simulasi.

Pelatihan menurut Sujoko (2012: 40) merupakan suatu proses membantu para tenaga kerja untuk memperoleh afektivitas dalam pekerjaan mereka yang sekarang atau yang akan datang melalui pengembangan kebiasaan tentang pikiran, tindakan, kecakapan, pengetahuan, dan sikap yang layak. Menurut Rivai, (2010: 226) pelatihan adalah proses secara sistematis mengubah tingkah laku pegawai untuk mencapai tujuan organisasi. Pelatihan berkaitan dengan keahlian dan kemampuan pegawai untuk melaksanakan pekerjaan saat ini. Pelatihan memiliki orientasi saat ini dan membantu pegawai untuk mencapai keahlian dan kemampuan tertentu agar berhasil dalam melaksanakan pekerjaannya.

Sedangkan metode simulasi ialah suatu metodologi untuk melaksanakan percobaan dengan menggunakan model dari suatu sistem nyata (Hasan, 2002: 34). Simulasi merupakan suatu model pengambilan keputusan dengan mencontoh atau mempergunakan gambaran sebenarnya dari suatu sistem kehidupan dunia nyata tanpa harus mengalaminya pada keadaan yang sesungguhnya. Simulasi adalah suatu teknik yang dapat digunakan untuk memecahkan model-model dari golongan yang luas. Simulasi mempelajari atau memprediksi sesuatu yang belum terjadi dengan cara meniru atau membuat model sistem yang dipelajari dan selanjutnya mengadakan eksperimen dengan 
menggunakan komputer (Hamdan dan Dessy, 2015: 94).

Berdasarkan uraian di atas, maka dilakukan penelitian dengan judul "Upaya Meningkatkan Kemampuan Guru Dalam Menggunakan Program Microsoft Office 365 Sebagai Media Pembelajaran Melalui Pelatihan dan Simulasi Di SD Negeri 3 Belikurip Tahun Pelajaran 2019/2020".

\section{METODE PENELITIAN}

Penelitian tindakan kelas ini dilaksanakan pada semester 1 tahun pelajaran 2019/2020 selama empat bulan. PTK adalah kegiatan mencermati suatu objek dengan menggunakan aturan-aturan tertentu untuk memperoleh informasi yang bermanfaat (Nurgiansah, Pratama, et al., 2021). Lokasi tempat penelitian adalah di SD Negeri 3 Belikurip yang beralamat di Tanjung RT 01 RW 08, Desa Belikurip, Kecamatan Baturetno, Kabupaten Wonogiri. Alasan pemilihan tempat penelitian ini adalah karena peneliti melihat adanya indikasi rendahnya kemampuan guru SD Negeri 3 Belikurip Tahun Pelajaran 2019/2020 dalam menggunakan program Microsoft Office 365 sebagai media pembelajaran. Subjek penelitian ini adalah guru SD Negeri 3 Belikurip Tahun Pelajaran 2019/2020 dengan jumlah 8 orang. Sedangkan objek penelitian ini adalah kemampuan guru SD Negeri 3 Belikurip Tahun Pelajaran 2019/2020 dalam menggunakan program Microsoft Office 365 sebagai media pembelajaran melalui pelatihan dan simulasi. Alat pengumpulan data dalam penelitian ini yaitu lembar penilaian dan pedoman observasi Validasi data hasil penilaian kemampuan guru dalam menggunakan program Microsoft Office 365 sebagai media pembelajaran menggunakan triangulasi data, yaitu peneliti mengkonfirmasikan hasil penilaiannya kepda guru yang dinilai.
Analisis data kemampuan guru dalam menggunakan program Microsoft Office 365 sebagai media pembelajaran pada kondisi awal, siklus I dan siklus II dilakukan dengan menggunakan analisis deskriptif komparatif. Analisis deskriptif komparatif dilakukan pada siklus I dan siklus II. Analisis data siklus I dilakukan dengan membandingkan hasil penilaian kemampuan guru kondisi awal dengam nilai hasil penilaian kemampuan guru pada siklus I. Sedangkan analisis data siklus II dilakukan dengan membandingkan hasil penilaian kemampuan guru pada siklus I dengan hasil penilaian kemampuan guru pada siklus II.

Keberhasilan suatau penelitian dapat dilihat dari pencapaian indikator kinerja. Indikator kerja dapat dilihat secara umum dengan membandingkan hasil penilaian kemampuan guru dari satu siklus ke siklus berikutnya. Indikator kinerja penelitian ini adalah sebagai berikut:

1. Adanya peningkatan kemampuan guru dalam menggunakan program Microsoft Office 365 sebagai media pembelajaran dari kondisi awal ke siklus I, dan dari siklus I ke siklus II.

2. Kemampuan dalam menggunakan program Microsoft Office 365 sebagai media pembelajaran pada semua guru SD Negeri 3 Belikurip minimal mencapai kualifikasi Baik.

Kualifikasi penilaian kemampuan guru dalam menggunakan program Microsoft Office 365 sebagai media pembelajaran adalah sebagai berikut.

Tabel 1. Kualifikasi Penilaian Kemampuan Guru

\begin{tabular}{|c|c|c|}
\hline No & Kualifikasi & Range Nilai \\
\hline 1. & Amat Baik & $91-100$ \\
\hline 2. & Baik & $71-90$ \\
\hline 3. & Cukup & $51-70$ \\
\hline 4. & Kurang & $\leq 50$ \\
\hline
\end{tabular}

Desain penelitian ini menggunakan desaian Penelitian Tindakan Sekolah (PTS) 
dengan rancangan model Kemmis dan Taggart yang terdiri dari atas empat langkah, yaitu: perencanaan, pelaksanaan, observasi dan refleksi (Arikunto, 2006: 93). Penelitian ini akan dilaksanakan dalam dua siklus. Alur tindakan dalam penelitian tindakan sekolah ini dapat digambarkan sebagai berikut.

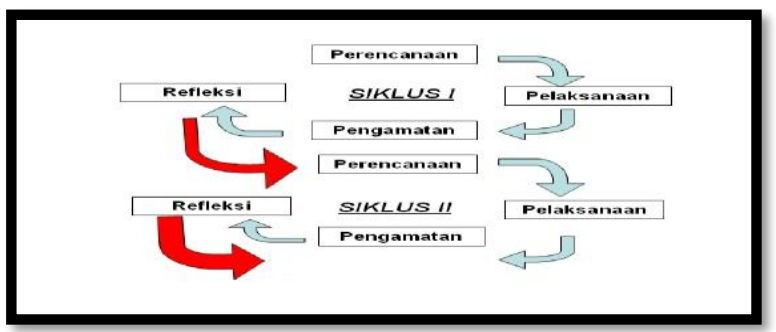

Gambar 1. Desain Penelitian Tindakan Sekolah

\section{HASIL PENELITIAN DAN PEMBAHASAN Hasil Penelitian \\ Deskripsi Kondisi Awal}

Hasil observasi kondisi awal menunjukkan bahwa: 1) kemampuan guru SD Negeri 3 Belikurip Tahun Pelajaran 2019/2020 dalam menggunakan program Microsoft Office 365 sebagai media pembelajaran masih rendah; 2) Kualitas proses pembelajaran dengan menggunakan media Microsoft Office 365 pembelajaran yang sudah dibuat oleh guru masih belum optimal; dan 3) Para guru kurang termotivasi dan belum percaya diri dalam menggunakan slide Microsoft PowerPoint sebagai media pembelajaran. Sedangkan secara empiris diperoleh fakta hasil penilaian kemampuan guru SD Negeri 3 Belikurip Tahun Pelajaran 2019/2020 dalam menggunakan program Microsoft Office 365 sebagai media pembelajaran sebagai berikut:

Tabel 2. Kemampuan Guru pada Kondisi Awal

\begin{tabular}{|c|c|c|}
\hline No & Predikat & Jumlah Guru (\%) \\
\hline 1 & Amat Baik & - \\
2 & Baik & 2 orang (25,0\%) \\
3 & Cukup & 4 orang (50,0\%) \\
4 & Kurang & 2 orang (25,0\%) \\
\hline \multicolumn{2}{|c|}{ Rata-rata } & 59,5 \\
\hline
\end{tabular}

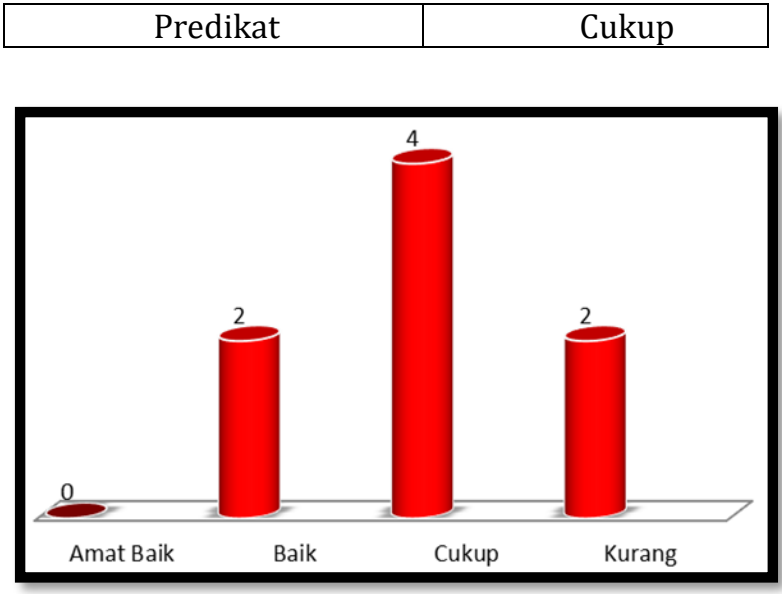

Gambar 2. Grafik Kemampuan guru pada Kondisi Awal

Dari data di atas menunjukkan bahwa pada kondisi awal, tidak ada guru yang kemampuanya masuk kualifikasi Amat Baik, hanya 2 orang guru $(25,0 \%)$ yang kualifikasinya Baik, ada 4 orang guru (50,0\%) yang kualifikasinya Cukup dan masih ada 2 orang guru $(25,0 \%)$ yang kualifikasinya Kurang. Nilai rata-rata kemampuan guru dalam menggunakan Microsoft Office 365 sebagai media pembelajaran adalah 59,5 masuk kualifikasi Cukup. Mengacu pada data tersebut maka penulis sebagai Kepala SD Negeri 3 Belikurip berencana untuk melaksanakan Penelitian Tindakan Sekolah (PTS) melalui pelatihan dan simulasi yang dilaksanakan pada siklus I.

\section{Pembahasan \\ Siklus I}

Hasil pengamatan terhadap aktivitas guru peserta pelatihan dan simulasi pada siklus I, diperoleh data kemampuan guru SD Negeri 3 Belikurip Tahun Pelajaran 2019/2020 dalam menggunakan program Microsoft Office 365 sebagai media pembelajaran sebagai berikut.

Tabel 3. Kemampuan Guru pada Siklus I

\begin{tabular}{|c|c|c|}
\hline No & Predikat & Jumlah Guru (\%) \\
\hline 1 & Amat Baik & 1 orang $(12,5 \%)$ \\
2 & Baik & 3 orang $(37,5 \%)$ \\
3 & Cukup & 4 orang $(50,0 \%)$ \\
\hline
\end{tabular}




\begin{tabular}{|c|c|c|}
\hline 4 & Kurang & - \\
\hline & $\begin{array}{c}\text { Rata-rata } \\
\text { Predikat }\end{array}$ & $\begin{array}{c}70,3 \\
\text { Cukup }\end{array}$ \\
\hline
\end{tabular}

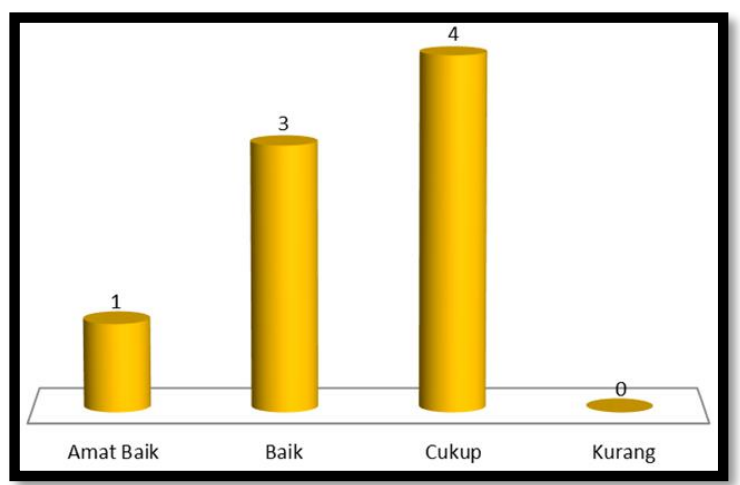

Gambar 3. Grafik Kemampuan Guru pada Siklus

Pada siklus I dilaksanakan tindakan penelitian melalui pelatihan dan simulasi. Pada siklus I ada 1 orang (12,5\%) yang kemampuannya masuk kualifikasi Amat Baik, 3 orang guru (37,5\%) yang kemampuannya masuk kualifikasi Baik, sebanyak 4 orang guru $(50,0 \%)$ yang kemampuannya masuk kualifikasi Cukup dan tidak ada yang kemampuannya masuk kualifikasi Kurang. Nilai rata-rata kemampuan guru dalam menggunakan Microsoft Office 365 sebagai media pembelajaran adalah 70,3 masuk kualifikasi Cukup. Kemampuan guru SD Negeri 3 Belikurip pada siklus I sudah meningkat, namun peningkatannya belum memenuhi indikator kinerja penelitian ini sehingga perlu dilanjutkan pada siklus II.

\section{Siklus II}

Pada siklus II, peneliti melaksanakan pelatihan dan simulasi secara kelompok dengan pendampingan intensif. Hasil penilaian kemampuan guru SD Negeri 3 Belikurip Tahun Pelajaran 2019/2020 dalam menggunakan Microsoft Office 365 sebagai media pembelajaran pada siklus II diperoleh data sebagai berikut.

Tabel 4. Kemampuan Guru pada Siklus II

\begin{tabular}{|c|c|c|}
\hline No & Predikat & Jumlah Guru (\%) \\
\hline 1 & Amat Baik & 2 orang (25,0\%) \\
2 & Baik & 6 orang (75,0\%) \\
3 & Cukup & - \\
4 & Kurang & - \\
\hline \multicolumn{2}{|c|}{ Rata-rata } & 81,1 \\
& Predikat & Baik \\
\hline
\end{tabular}

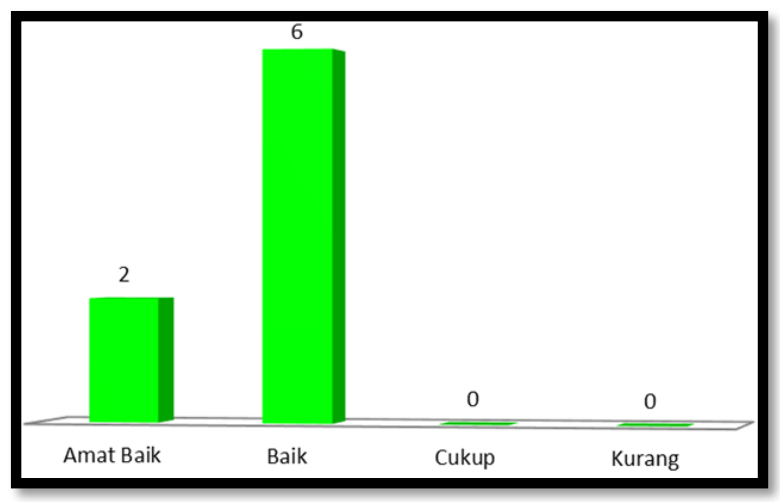

Gambar 4. Grafik Kemampuan Guru pada Siklus II

Pada siklus II peneliti melaksanakan tindakan penelitian melalui pelatihan dan simulasi secara kelompok dengan pendampingan intensif. Pada siklus II ada 2 orang guru $(25,0 \%)$ yang kemampuannya masuk kualifikasi Amat Baik, sebanyak 6 orang guru $(75,0 \%)$ yang kemampuannya masuk kualifikasi Baik, dan tidak ada guru yang kemampuannya masuk kualifikasi Cukup maupun Kurang. Nilai rata-rata kemampuan guru SD Negeri 3 Belikurip dalam menggunakan Microsoft Office 365 sebagai media pembelajaran adalah 81,1 masuk kualifikasi Baik. Peningkatan kemampuan guru SD Negeri 3 Belikurip dalam menggunakan Microsoft Office 365 sebagai media pembelajaran pada siklus II sudah berhasil mencapai semua indikator kinerja penelitian sehingga tidak perlu dilanjutkan pada siklus berikutnya.

Pelatihan dan Pengembangan SDM merupakan faktor penting dalam sebuah organisasi untuk mencapai tujuan organisasi secara efektif dan efisien (Rohmah, 2018). Hal tersebut senada dengan apa yang telah dilakukan oleh peneliti yaitu memberikan pelatihan dan 
simulasi kepada guru SD supaya memiliki kualifikasi atau kemampuan dalam menggunakan Microsoft office 365 sebagai media pembelajaran. Kemampuan guru untuk mengaplikasikan Microsoft office di masa sekarang ini merupakan sesuatu yang penting bagi keberhasilan proses pembelajaran di sekolah (Usodo et al., 2016). Media pembelajaran merupakan sarana bagi para guru untuk menyampaikan materi belajar kepada peserta didik. Kesuksesan seorang guru dalam menyempaikan materi pembelajaran salah satunya dipengaruhi oleh media yang digunakan(Sulastri et al., 2014).

Mengacu pada hasil penelitian, setelah dilaksanakan tindakan penelitian melalui pelaksanaan pelaksanaan pelatihan dan simulasi pada siklus I dan siklus II, diperoleh data empiris peningkatan kemampuan guru SD Negeri 3 Belikurip Tahun Pelajaran 2019/2020 dalam menggunakan program Microsoft Office 365 sebagai media pembelajaran sebagai berikut:

Tabel 5. Peningkatan Kemampuan Guru Dari Kondisi Awal, Siklus I dan Siklus II

\begin{tabular}{|c|c|c|c|}
\hline Aspek & Kondisi Awal & Siklus I & Siklus II \\
\hline Kegiatan & $\begin{array}{c}\text { Belum } \\
\text { melaksanakan } \\
\text { pelatihan dan } \\
\text { simulasi }\end{array}$ & $\begin{array}{l}\text { Pelatihan } \\
\text { dan } \\
\text { simulasi } \\
\text { secara } \\
\text { kelompok }\end{array}$ & $\begin{array}{l}\text { Pelatihan } \\
\text { dan } \\
\text { simulasi } \\
\text { secara } \\
\text { kelompok } \\
\text { dengan } \\
\text { bimbingan } \\
\text { intensif }\end{array}$ \\
\hline $\begin{array}{c}\text { Amat } \\
\text { Baik } \\
\text { Baik } \\
\text { Cukup } \\
\text { Kurang }\end{array}$ & $\begin{array}{c}- \\
2 \text { orang } \\
(25,0 \%) \\
4 \text { orang } \\
(50,0 \%) \\
2 \text { orang } \\
(25,0 \%)\end{array}$ & $\begin{array}{c}1 \text { orang } \\
(12,5 \%) \\
3 \text { orang } \\
(37,5 \%) \\
4 \text { orang } \\
(50,0 \%) \\
-\end{array}$ & $\begin{array}{c}2 \text { orang } \\
(25,0 \%) \\
6 \text { orang } \\
(75,0 \%) \\
- \\
-\end{array}$ \\
\hline $\begin{array}{c}\text { Rata- } \\
\text { rata } \\
\text { Predikat }\end{array}$ & $\begin{array}{c}59,5 \\
\text { Cukup }\end{array}$ & $\begin{array}{c}\text { 70,3 } \\
\text { Cukup }\end{array}$ & $\begin{array}{l}\mathbf{8 1 , 1} \\
\text { Baik }\end{array}$ \\
\hline
\end{tabular}

Berdasarkan data di atas membuktikan bahwa melalui pelatihan dan simulasi dapat meningkatkan kemampuan guru SD Negeri 3 Belikurip. Pada kondisi awal belum dilaksanakan pelatihan dan simulasi. Pada kondisi awal, tidak ada guru yang kemampuanya masuk kualifikasi Amat Baik, hanya 2 orang guru $(25,0 \%)$ yang kualifikasinya Baik, ada 4 orang guru $(50,0 \%)$ yang kualifikasinya Cukup dan masih ada 2 orang guru $(25,0 \%)$ yang kualifikasinya Kurang. Nilai rata-rata kemampuan guru dalam menggunakan Microsoft Office 365 sebagai media pembelajaran adalah 59,5 masuk kualifikasi Cukup.

Pada siklus I dilaksanakan tindakan penelitian melalui pelatihan dan simulasi. Pada siklus I ada 1 orang (12,5\%) yang kemampuannya masuk kualifikasi Amat Baik, 3 orang guru $(37,5 \%)$ yang kemampuannya masuk kualifikasi Baik, sebanyak 4 orang guru (50,0\%) yang kemampuannya masuk kualifikasi Cukup dan tidak ada yang kemampuannya masuk kualifikasi Kurang. Nilai rata-rata kemampuan guru dalam menggunakan Microsoft Office 365 sebagai media pembelajaran adalah 70,3 masuk kualifikasi Cukup.

Pada siklus II peneliti melaksanakan tindakan penelitian melalui pelatihan dan simulasi secara kelompok dengan pendampingan intensif. Pada siklus II ada 2 orang guru $(25,0 \%)$ yang kemampuannya masuk kualifikasi Amat Baik, sebanyak 6 orang guru $(75,0 \%)$ yang kemampuannya masuk kualifikasi Baik, dan tidak ada guru yang kemampuannya masuk kualifikasi Cukup maupun Kurang. Nilai rata-rata kemampuan guru SD Negeri 3 Belikurip dalam menggunakan Microsoft Office 365 sebagai media pembelajaran adalah 81,1 masuk kualifikasi Baik.

Jadi melalui pelatihan dan simulasi dapat meningkatkan pelatihan dan simulasi dapat meningkatkan kemampuan guru SD Negeri 3 Belikurip Tahun Pelajaran 2019/2020 dalam menggunakan 
program Microsoft Office 365 sebagai media pembelajaran. Dari kondisi awal tidak ada guru yang kemampuannya Amat Baik dan hanya 2 orang guru $(25,0 \%)$ yang kualifikasinya Baik dengan nilai rata-rata kompetensi guru hanya 59,5 (Cukup). Meningkat pada siklus I menjadi ada 1 orang $(12,5 \%)$ yang kemampuannya Amat Baik dan 3 orang guru $(37,5 \%)$ yang kemampuannya Baik dengan nilai rata-rata kompetensi guru adalah 70,3 (Cukup). Meningkat lagi pada siklus II menjadi 2 orang guru $(25,0 \%)$ yang kemampuannya Amat Baik dan sebanyak 6 orang guru $(75,0 \%)$ yang kemampuannya Baik dengan nilai rata-rata kompetensi guru 81,1 (Baik).

Hasil penelitian ini sejalan dengan apa yang sudah dilakukan oleh (Fitriana,
2020) dikatakan bahwa melalui kegiatan pelatihan dapat memberikan dampak pada kualitas dan kompetensi individu dalam mengerjakan sesuatu. Pelatihan yang tepat dapat merangsang individu belajar untuk mengaplikasikan sesuatu yang dipelajari di dalam pelatihan tersebut.

\section{KESIMPULAN}

Berdasarkan hasil penelitian dan pembahasan penelitian, maka dapat disimpulkan bahwa melalui pelatihan dan simulasi dapat meningkatkan kemampuan guru SD Negeri 3 Belikurip Tahun Pelajaran 2019/2020 dalam menggunakan program Microsoft Microsoft Office 365 sebagai media pembelajaran.

\section{DAFTAR PUSTAKA}

Falahudin, I. (2014). Pemanfaatan Media dalam Pembelajaran. Jurnal Lingkar Widyaiswara, $1(4), 104-117$.

Fitriana, F. (2020). Pelaksanaan Pelatihan Dan Pengembangan SDM Divisi Customer Service Di PT. Bank Lampung KCP Natar. Adzkiya: Jurnal Hukum Dan Ekonomi Syariah, 8(1), 1. https://doi.org/10.32332/adzkiya.v8i1.2113

Handayani, S., \& Hadi, S. (2020). Pelatihan E-Learning Menggunakan Office 365 Bagi GuruGuru dan Siswa-Siswa Madrasah Aliyah Negeri 1 Semarang. JPKMI Uurnal Pengabdian Kepada Masyarakat Indonesia), 1(2), 49-58. https://doi.org/10.36596/jpkmi.v1i2.32

Khoirudin, M. (2019). Model Pembelajaran Make A Match Untuk Meningkatkan Motivasi Dan Hasil Belajar Mendeskripsikan Nilai Juang Pancasila Sebagai Dasar Negara Pada Siswa Kelas Vi SDN I Guwotirto Tahun Pelajaran 2013/2014. Elementary School, 6(2), 190-195.

Miftah, M. (2014). Pemanfaatan Media Pembelajaran Untuk Peningkatan Kualitas Belajar Siswa. Jurnal Kwangsan, 2(1), 1. https://doi.org/10.31800/jurnalkwangsan.v2i1.11

Muhson, A. (2010). Pengembangan Media Pembelajaran Berbasis Teknologi Informasi. Jurnal Pendidikan Akuntansi Indonesia, 8(2). https://doi.org/10.21831/jpai.v8i2.949

Nurgiansah, T. H. (2021). Pelatihan Penelitian Tindakan Kelas Bagi Guru Pendidikan Kewarganegaraan Di Sekolah Menengah Atas Se-Kabupaten Bantul. BERNAS: Jurnal Pengabdian Kepada Masyarakat, 2(1), 28-33. https://doi.org/10.31949/jb.v2i1.566

Nurgiansah, T. H., Hendri, \& Khoerudin, C. M. (2021). Role Playing Dalam Pembelajaran Pendidikan Pancasila dan Kewarganegaraan. Jurnal Kewarganegaraan, 18(1), 56-64. https://doi.org/10.24114/jk.v18i1.22597

Nurgiansah, T. H., Pratama, F. F., \& Iman, A. S. (2021). Penelitian Tindakan Kelas Dalam Pendidikan Kewarganegaraan. Jurnal Pendidikan Pancasila Dan Kewarganegaraan, 2(1), 10-23.

Nurgiansah, T. H., \& Pringgowijoyo, Y. (2020). Pelatihan Penggunaan Model Pembelajaran Jurisprudensial Pada Guru Di KB TK Surya Marta Yogyakarta. KUAT: Keuangan Umum Dan Akuntansi Terapan. PKNSTAN, 2(1). 
Rohmah, N. F. (2018). Pelatihan dan Pengembangan Sumber Daya Manusia. Intizam: Jurnal Manajemen Pendidikan Islam, 2(1), 1-11.

Siahaan, M. (2020). Dampak Pandemi Covid-19 Terhadap Dunia Pendidikan. Jurnal Kajian Ilmiah, 1(Juli), 1-3. https://doi.org/10.31599/jki.v1i1.265

Sulastri, S., Imran, I., \& Firmansyah, A. (2014). Meningkatkan hasil belajar siswa melalui strategi pembelajaran berbasis masalah pada mata pelajaran IPS di. Jurnal Kreatif Online, $3(1)$.

Suprianto. (2018). Perancangan E-Learning Menggunakan Office 365 Dalam Proses Belajar Mengajar. Seminar Nasional Royal, 9986(3September), 381-386.

Usodo, B., Kurniawati, I., \& Kuswardi, Y. (2016). Pelatihan Penerapan Beberapa Aplikasi Dari Microsoft: Office Mix , Onenote, Sway Dalam Pembelajaran Bagi Guru-Guru Matematika. Jurnal Elektronik Pembelajaran Matematika, 4(9), 743-752. 